\title{
Poland's Position on the Investment Development Path
}

\begin{abstract}
In the modern world based on open national economies, individual countries are closely related and even interdependent in terms of trade, investment flows, labor migration, as well as cooperation at the level of enterprises. The role of enterprises in foreign markets in the form of FDI is growing, while the national economies compete for the inflow of such capital. Due to the fact that since the 1990s Poland has been extensively involved in internationalization processes, it seems important to find answers to the questions: how has the inflow of FDI into the country evolved over the years; what position have Polish investors built in foreign markets during this time; and, finally, what is the current position of Poland on the investment development path. To answer these questions, research tools such as the review of domestic and foreign literature were used and desk research (based on NBP and UNCTAD statistical databases) was carried out to determine the position of the Polish economy in the IDP model. The analyses indicate that since 2008, Poland has been moving towards the third phase of the IDP model in a slow but steady manner.
\end{abstract}

Key words: Foreign Development Investment (FDI), Investment Development Path Model (IDP Model), Poland

JEL Classification: F21, F23, O10.

\section{Introduction}

In the globalized world, foreign direct investment (FDI), apart from foreign trade, plays an increasingly important role. In macroeconomic terms, FDI is an important factor in economic growth and development. It also increases the competitiveness of the economy. In microeconomic terms - for enterprises - it provides an opportunity for growth through internationalization. The reference literature and numerous discussions of practitioners and economic commentators raise this issue in the meticulous analyses of the importance of FDI for the entire global economy, its individual regions, sectors and enterprises operating within them, professional groups or societies.

International capital flows in the form of FDI allow for the assessment of the position of a given country on the investment development path. In this context, the model of investment development path (IDP) proposed by J. H. Dunning may be useful. This concept combines microeconomic considerations within the framework of the eclectic FDI and the macroeconomic approach, thanks to linking investment decisions of entrepreneurs with the level of economic development of a country (Rymarczyk, 2004).

Based on the available NBP and UNCTAD statistical data, it can be concluded that since the early 1990s, Poland has been gaining in significance, on the one hand, as an attractive recipient of FDI and, on the other hand, as an increasingly active exporter of such capital. It should be noted that although Poland has been a net importer of foreign direct investment since the beginning of its economic transformation, Polish entrepreneurs

${ }^{1} \mathrm{PhD}$, Department of Enterprise Management, Faculty of Management, University of Economics in Katowice, 1 Maja 50,40-287 Katowice, e-mail: katarzyna.zak@ue.katowice.pl; https://orcid.org/0000-0002-9212-7206 
recognize the positive aspects of foreign expansion. Their presence on world markets attests to the maturity of the economy and contributes to further economic development. As a result of the internationalization of their activity, Polish investors gain experience and technologies, and increase the value of their companies. This leads to increased competitiveness on regional and global markets.

The article aims to present the investment situation of Poland in terms of imported and exported foreign direct investments. The starting point of the study is the IDP model, while the main indicator under analysis is the NOI per capita. The research period covered the years 1990-2017.

The article uses the following research tools: the review of domestic and foreign literature, as well as desk research, based on data from the NBP and UNCTAD statistical databases.

\section{Foreign Direct Investment (FDI) - Conceptualization}

The processes of the internationalization of an economy and its enterprises have been accompanied, especially since the 1980s, by the dynamic development of international capital flows in the form of direct foreign investments (FDI). Foreign direct investment is understood as investment made in a country other than the investor's country of origin, consisting in the depositing of capital - usually long-term - in a foreign enterprise in order to obtain effective control of this enterprise and achieve financial profit. Investment of this type includes: a purchase of shares in existing foreign companies, the establishment of a new subsidiary abroad, the establishment of a joint venture with a foreign entity and the acquisition of real estate abroad to extend the existing activity (Krugman, Obstfeld, 2007). According to the OECD nomenclature (2008), direct investment is made when a foreign investor has a stake of at least $10 \%$ of shares or votes in a given enterprise, and while it does not have to exercise absolute control over the company, it is important that it has an influence on its management. Direct investment may take the form of greenfield investment (i.e. starting a completely new business), brownfield investment (i.e. the acquisition of an existing enterprise for example through privatization) or capital involvement in an enterprise (if the threshold of $10 \%$ is exceeded).

In the reference literature, a number of theories explain why investors invest their capital abroad, for example: the theory of monopolistic advantages, the theory of the international product life cycle, theory of location, the theory of internalization. However, the most frequently quoted theory that constitutes their synthesis is the eclectic theory of international production by J. H. Dunning (2000), also called the OLI paradigm. According to this theory, the prerequisite for FDI is the simultaneous occurrence of three factors (Budnikowski, 2006). First of all, ownership, i.e. having access to, for example, capital, resources of qualified workforce and managerial staff, raw materials, unique technology, information, management methods, brand, monopolistic position, research potential. Second, location, i.e. the advantage which concerns the attributes describing the attractiveness of the foreign market, e.g. a dynamically developing market, low prices of basic production factors, high qualifications and productivity of the workforce, transport accessibility, low transport costs, the friendly attitude of a host society to foreign capital, favorable legislation. Finally, the third factor is internalization, which means that international transactions within the company are more favorable than transactions 
concluded in the free market. Establishing a subsidiary abroad allows an enterprise to protect technology and provides the possibility of coordination and vertical integration. Apart from the classic OLI model, in their decisions to choose FDI to expand into foreign markets, enterprises take into account both the standard - "hard" - factors and other - so called "soft" - factors which constitute a specific "value added" to a location. Here, we can distinguish the character of the labor market, infrastructure of economic activity, economic climate, public relations of the place or cultural determinants (Rosińska-Bukowska, 2009).

Foreign direct investment causes a lot of controversy. The arguments in its favor include: the possibility of increasing production, employment and labor productivity in the country, access to modern and effective technologies, know-how and management techniques, the opportunity to improve the balance of payments, the ability to finance restructuring and development processes in a way which is safer compared to foreign loans, and the stimulation of the activity of domestic producers, improved quality of products, consumer access to new products and services as a result of increased competition on the domestic market. The main threats include: the risk of an unfavorable balance of payments, deterioration of terms of trade and reduced tax revenues resulting from foreign transfer pricing by foreign companies, weaker competition and the emergence of a local monopoly by a foreign company, bankruptcy of local companies, taking over control of domestic branches by increasing competition on the domestic market, which local companies are not able to cope with, limiting the effects of macroeconomic policy in a situation where the participation of investors (international corporations) in the production of a given country is high and financing their operations comes mainly from abroad, a threat to the natural environment due to the transfer of obsolete or so-called dirty technologies from abroad, the acquisition of domestic enterprises with the aim to liquidate them, deepening development disparities by concentrating FDI in the most attractive industries and regions of a country, a threat to the sovereignty of a state in the situation of taking control over strategic industries and sectors of the economy (Nowara, 2001).

\section{Characteristic of the IDP Model}

The phenomenon of investing capital in the form of foreign direct investments is connected with changes in the competitive position of individual countries on the international arena. This fact was examined and described (Dunning 1981, Dunning, Narula 1996) as the Investment Development Path (IDP model). J.H. Dunning showed that there is a relationship between the level of GDP per capita and the size of net investment per capita. At the same time, net investments (NOI - net outward investment rate) are the difference between foreign investments undertaken by economic entities in a given country and foreign investments realized by foreign entities in the territory of that country (Stawicka, 2008). According to the IDP model, initially low-developed countries attract investment using local resources of raw materials and cheap labor, while they do not undertake investment abroad. In the course of industrialization and the shift of comparative advantages from labor-intensive to capital-intensive industries, the rationale behind FDI changes. In the most developed countries, investors look for strategic resources, such as access to technologies, research facilities, and human capital. At the same time, the assets accumulated in the economy become the foundation for the effective international expansion of domestic enterprises. In the IDP model, depending on the value of the NOI 
indicator and its tendency, five phases can be distinguished. Their characteristics are presented in Table 1 .

Table 1. Stages in the IDP Model

\begin{tabular}{|c|c|}
\hline Phase & Characteristics \\
\hline I & $\begin{array}{l}\text { This phase is characterized with a gradual, but slow increase in FDI inflow to a given economy. } \\
\text { These investments are mainly focused on the use of natural assets of the target country. FDI of } \\
\text { domestic enterprises is practically non-existent; they are still not ready to undertake the most active } \\
\text { forms of internationalization. The value of the NOI in this phase is negative - initially close to zero, } \\
\text { and gradually increasing over time. }\end{array}$ \\
\hline II & $\begin{array}{l}\text { In this phase there is a further, increasingly more intensive inflow of direct investments to the } \\
\text { economy, aimed at capturing market share and using cheap resources (mainly labor). At the same } \\
\text { time, the structure of the national economy is changing - the share of capital-intensive production } \\
\text { branches is increasing (e.g. chemicals, metals and metal products, electrical devices). The first } \\
\text { attempts are made by domestic enterprises to expand internationally. The values of the NOI index } \\
\text { are still negative and declining; however, at the end of this phase, the dynamics of this decline are } \\
\text { clearly slowing down. This is the result of a steady increase in the value of FDI implemented by } \\
\text { enterprises from the host economy. }\end{array}$ \\
\hline III & $\begin{array}{l}\text { In this phase, the value of FDI implemented by domestic enterprises increases dynamically. The } \\
\text { dynamics exceed the dynamics of FDI inflow. This means that the value of the NOI - although still } \\
\text { negative - begins to increase gradually. The economies of the countries in the third phase of IDP } \\
\text { are included in the group of industrialized countries, whose competitiveness is increasingly } \\
\text { attributed to innovation and skilled workforce, and not only to investment. The main driver of FDI } \\
\text { is to look for opportunities to improve the global effectiveness of the entire corporation. }\end{array}$ \\
\hline IV & $\begin{array}{l}\text { In this phase, the stream of investments flowing out of the economy increases faster than the inflow } \\
\text { of investments, which results in the NOI adopting positive values. The economy becomes the net } \\
\text { capital exporter. Its location advantages for FDI include accumulated intangible assets (e.g. } \\
\text { technology, know-how, knowledge), and the entire economy is perceived as a developed economy. } \\
\text { The economy is also characterized by innovation and high research and development expenditures. }\end{array}$ \\
\hline $\mathrm{V}$ & $\begin{array}{l}\text { In this phase there is a further dynamic growth in both FDI inflows and capital exports in the form } \\
\text { of FDI of domestic enterprises. Depending on the temporary advantage of one or the other, the } \\
\text { value of the NOI index changes - in principle, however, its fluctuates around zero. Phase V is } \\
\text { characteristic of the most developed, innovative, knowledge-based economies. }\end{array}$ \\
\hline
\end{tabular}

Source: Author's own elaboration based on (Dunning, Lundan, 2008; Gorynia, Nowak, Wolniak, 2009; Ferencikova, Ferencikova, 2012)

The classic approach to the IDP model has been empirically verified and expanded in a number of studies. One of the more interesting approaches is to include foreign trade in this concept. It turns out that the structure of foreign trade demonstrates similar tendencies to changes in relation to economic growth, such as foreign direct investment. It was noted that the development path coincides with a gradual change in the export structure. In the initial stages of economic development, it is based mainly on raw materials, natural and low-processed products. Economic development is accompanied by changes in the structure of exports, which tend to be dominated by highly processed, capital-intensive and innovative products (Dunning, Kim and Lin, 2001). 


\section{Foreign direct investment in Poland and direct investment by Polish enterprises}

Since the early 1990s, the countries of Central and Eastern Europe, including Poland, have been attractive for investors. An increased interest in this part of the world was influenced above all by the changes related to the post-communist transformation of the region, integration processes with the structures of the European Union, favorable labor cost index and fast-growing markets. According to the E\&Y Report (2017), the countries of Central and Eastern Europe rank third, behind Western Europe and the USA, among the most attractive regions of the world in terms of foreign investment. Moreover, Central and Eastern Europe has seen the greatest rise among all regions, catching up with China.

In terms of FDI in absolute terms (Figure1), Poland belongs to the group of the most attractive countries in Europe and is a leader in Central and Eastern Europe. Since the beginning of the transformation, the value of direct investment has steadily increased, to the highest value in 2007 - USD 1,909 million. The years 2008-2009 saw a decline in the value of FDI caused by the global economic crisis. Although the next years witnessed an increase in the value of capital in the form of FDI located in Poland, the record from 2007 has not yet been repeated. In 2012, the Polish economy reported a significant decrease (by 33\%) in FDI compared to the previous year. The year 2013 was another year of decline in the inflow of direct investment to Poland - not only compared to 2012, but over the previous ten years. This can be attributed to such developments as: the liquidation of special purpose entities and the withdrawal of capital in transit, the sale of shares in the banking sector to foreign portfolio investors, the limited activity of certain financial companies and the withdrawal of shares by foreign investors. The years 2014-2016 marked a renewed interest of foreign investors in Poland. In 2017, there was another fall - the FDI value did not exceed USD 6.5 million. In its opinion, the National Bank of Poland (NBP) stated that the situation was caused by transactions in which residents purchased shares in Polish companies from direct investors (NBP).

Based on NBP statistics, it can be concluded that prior to Poland's EU accession, the share of FDI in this area was high and amounted to $74 \%$, and then systematically increased to reach $92 \%$ in 2016 . In 2003 , the highest FDI values came from such countries as the Netherlands, France, Germany, Austria, the United Kingdom, and from outside Europe the USA and South Korea. In 2016, the largest inflow of FDI was recorded from the Netherlands, Germany and Luxembourg, and from outside Europe: Japan, Israel and the USA. Before the accession to the European Union, most funds in the form of FDI were invested in entities operating in the field of industrial processing, trade and repairs $(61 \%)$, real estate services, IT, science, machinery rental and other services related to conducting economic activity (14\%), financial intermediation (11\%), and electricity, gas and water supply (10\%). In 2016, foreign direct investment was primarily addressed to entities involved in construction trade and repairs for hotels, transports, communication $(36 \%)$, as well as real estate and business activities (30\%) and manufacturing (29\%) (NBP).

Polish enterprises also invest abroad more extensively and their investment activity has increased on global markets. In the early 1990s, FDI of Polish enterprises accounted for only $0.01 \%$ of global FDI flows, while towards the late 2010 's, this value increased to $0.4 \%$, and in 2016 exceeded $0.43 \%$ (which is a 43 -fold increase). This phenomenon is an important signal of changes taking place in the Polish economy and indicates the level of its 
internationalization. Investment activity reflects the growing potential of Polish enterprises that are becoming active participants in the international system of trading in investment capital.

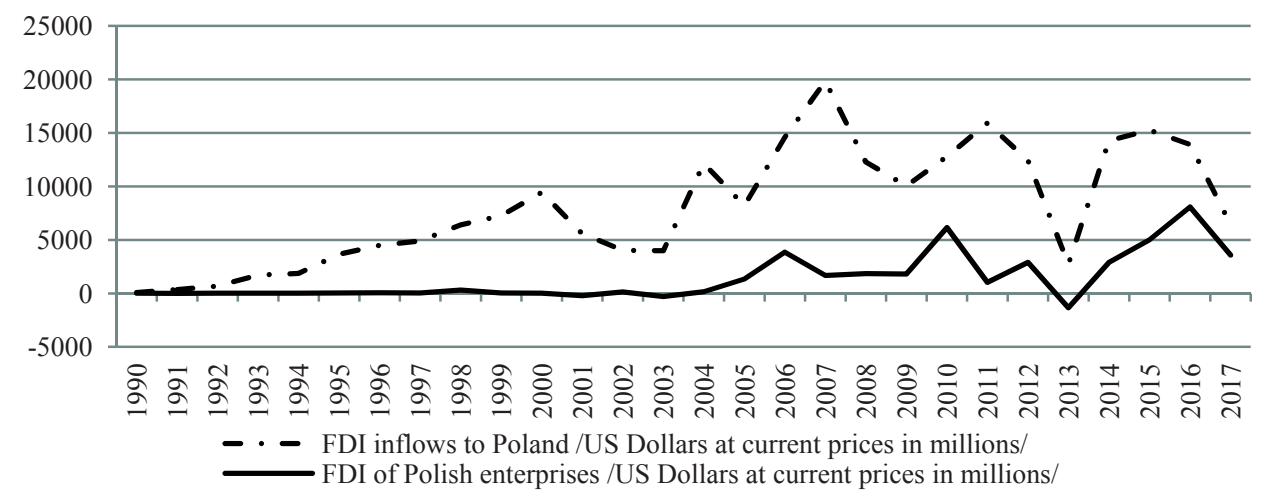

Fig. 1. FDI inflows to Poland and FDI of Polish enterprises, 1990-2017

Source: Author's own elaboration based on UNCTAD. Database.

The dynamic growth of FDI value of Polish entrepreneurs has been particularly visible since 2005, when - for the first time - the value of exported capital exceeded USD 1.3 billion, while another record was broken in 2010 in the amount of USD 6.15 billion and, finally, in 2016 - USD 8.7 billion. In turn, in 2013, the largest divestments of Polish entrepreneurs on foreign markets took place - amounting to over USD 1.5 billion.

According to NBP data, approximately $83 \%$ of Polish FDI is located in the EU countries. In terms of the number of operating companies, Polish entrepreneurs mainly choose neighboring countries, such as Germany, the Czech Republic, Ukraine or Russia, as the location for foreign investments. This situation confirms the thesis that the proximity of markets, the lack of regulatory barriers or good acquaintance with markets determine the choice of investment location. In turn, the reason for capital flows to such countries as Luxembourg, the Netherlands or Cyprus is favorable tax regulations. Companies register companies in these countries and invest through them (so-called capital in transit). In contrast, Belgium and the United Kingdom are large financial centers - here financial surpluses are allocated from the entire capital group (Żak, 2017). In 2016, the largest, yet single transactions were made in Luxembourg (USD 4.8 billion) and Sweden (USD 989 million), moreover, a relatively high transaction value was recorded in Hungary (USD 927 million) and outside Europe - in Canada (USD 702 million).

In 2016, approximately 65\% of Polish FDI was carried out through mergers and acquisitions in foreign markets. The industry-based cross-section of Polish FDI transactions changed significantly. However, this did not stem from the emergence of new trends, but was the result of large individual transactions made by Polish investors. In 2016, investments of the highest value went to entities conducting professional, scientific and technical activities (USD 2.4 billion), to entities related to information and communication (USD 1.7 billion) and entities associated with wholesale and retail trade; repair of motor vehicles and motorcycles (USD 992 million) (NBP). 


\section{The assessment of Poland's investment position based on the IDP Model}

The assessment of Poland's position on the investment path based on the IDP model was developed on the basis of data on FDI realized in Poland and by Polish investors, calculated per capita, in the years 1990-2017. For each period, the value of NOI per capita was determined (Fig. 2). In his discussion of the successive phases of the IDP model, H.J. Dunning showed that there is a relationship between the level of GDP per capita and the size of net investment per capita. In order to determine the position of Poland in a given phase of the IDP model, the data concerning the classification of national economies based on the GDP per capita in 2017 were used (IMF). Accordingly, the following countries were distinguished: countries with a low level of economic development: GDP below USD 2,000 per capita, countries with a low average level of economic development: GDP of USD 2,000-10,000 per capita, countries with a higher average level of economic development: GDP of USD 10,000-35,000 per capita, countries with a high level of economic development: GDP of USD 35,000-50,000 per capita, and countries with a very high level of economic development: GDP of over USD 50,000 per capita.

Taking into account the values of NOI per capita and the trend determined on their basis, together with the information on GDP per capita in Poland, the following observations can be made:

- At the beginning of the transformation in 1990, GDP per capita did not exceed USD 2,000 in Poland. The value of foreign capital in the Polish economy was low and there were practically no foreign investments pursued by Polish entrepreneurs. According to the model described by Dunning, the Polish economy was in the first phase of the IDP model.

- In the years 1991-2007 we can observe a gradual improvement in the GDP per capita level. In 1991, its value amounted to USD 2,247, to gradually increase in subsequent years, exceeding USD 10,000 in 2007 and reaching USD 11,194. This means that Poland was included in the group of countries with a lower average level of economic development. During this period, we also observe a dynamic growth in the value of direct investment in Poland. In 2007, its value was 55 times as high as in 1991. However, this was not a consistent period. In the years 1991-2000, there was a steady increase in the inflow of investment to Poland from USD 359 million to USD 9,445 million. It was a 26-fold growth. In the years 2001-2003, the value of FDI flowing to Poland decreased significantly (by nearly 58\%) to increase again in 2004 to USD 12,140 million. Also, in the following years, except for 2005 , there was a dynamic growth in foreign investment to Poland, with a record value in 2007 - USD 19,836 million. The foreign investment of Polish entrepreneurs in 1991-1996 grew slowly but steadily. In the subsequent years, FDI pursued by Polish investors fluctuated between higher and lower values, or even negative values, which marked the withdrawal of capital from foreign markets. Increasingly higher FDI values in Poland and higher but variable values of Polish foreign investment caused that in 1991-2000 the NOI per capita reached consistently lower values, while in 2001-2003 it increased slightly, only to decline again to USD 473 per capita and in the subsequent years until 2007. The characteristics of the presented data and the NOI per capita trend prove that the Polish economy in the discussed period was in the second phase of the IDP model. 


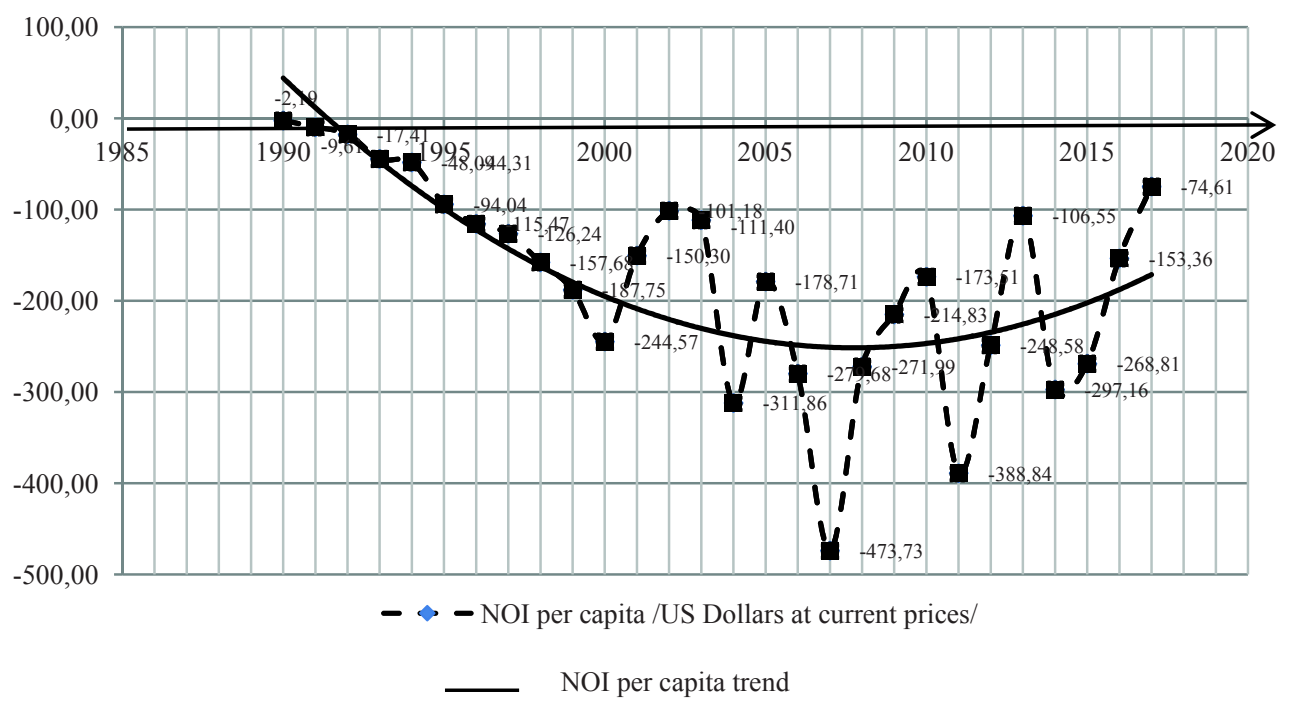

Fig. 2. NOI per capita in Poland, 1990-2017

Source: Author's own elaboration.

- Since 2008, GDP per capita has adopted variable values, but remained above USD 11,000. The highest value was achieved in 2014 - USD 14,237. This means that Poland can be included in the group of countries with a higher average level of economic development. After 2007, the value of imports of foreign investments in Poland assumed fluctuating values in the subsequent years, but it can be estimated that their average value amounted to over USD 11,600 million annually. The value of exports of Polish investments in the years 2008-1017 was also variable, but there were such years as 2010, when Polish foreign investments exceeded USD 6,100 million, or 2016, when Polish FDI accounted for 58\% of the FDI located in Poland. This means that NOI per capita has slowly picked up in the last ten years (trend line). Consequently, it can be assumed that the Polish economy has entered the initial stage of the third phase of the investment development path model. An additional argument supporting such a conclusion is the fact that changes in the structure of FDI flowing into Poland can also be observed, i.e. investment in pharmaceuticals, aviation or electronics as well as in the areas requiring the employment of a highly qualified workforce, such as financial intermediation, consulting and business services, are becoming increasingly important.

\section{Conclusion}

The political and economic changes taking place in Poland, and the ongoing process of internationalization and integration with the European Union, mean that we can observe 
increasingly more dynamic flows of capital to the Polish economy in the form of foreign direct investments as well as foreign direct investment pursued by Polish entrepreneurs.

The trend for the synthetic NOI index in the years 1990-2017 presented in the article leads to the conclusion that Poland's investment position is changing very slowly but steadily. Increasingly, we deal with the inflow of more capital-intensive and technologically advanced FDI. The growing value of Polish investment exports is also a positive factor. Although the values of NOI per capita in the subsequent years indicate that Poland is a net FDI importer, it can be stated, based on the presented trend line of the index, that the Polish economy is at the threshold of the third phase of H.J. Dunning's model. To maintain this positive trend, efforts should be constantly made to reinforce the strengths of the Polish economy which attract foreign investors, i.e. to maintain stable economic growth (supported by high positions in international investment attractiveness rankings), to foster development and high qualifications of employees, to fuel cooperation within the European Union. Moreover, in order to encourage the desired foreign capital and increase the attractiveness of Polish foreign investment exports, it is necessary to increase R\&D expenditures and intensify the implementation and application of product, technological, management or marketing innovations. In the face of the relatively high economic growth observed in Poland for several years and the improved innovation-oriented attitude, a further increase in the NOI index should be expected and Poland should take a more advantageous position on the IDP curve.

\section{References}

Budnikowski, A. (2006). Międzynarodowe stosunki gospodarcze (International Economic Relationships). PWE, Warszawa.

Dunning, J.H. (1981). Explaining the international direct investment position of countries: towards a dynamic or developmental approach. Weltwirtschaftliches Archiv, 117, 30-64

Dunning, J.H., Narula, R. (1996). The Investment Development Path revisited: some emerging issues. In: J.H. Dunning, R. Narula (red.) Foreign direct investment and governments. Catalysts for economic restructuring. London-New York: Routledge, 1-41.

Dunning, J.H. (2000). The eclectic paradigm as an envelope for economic and business theories of MNE activity. International Business Review, 9, 163-164

Dunning, J.H., Kim, Ch.-S., Lin, J.-D. (2001). Incorporating trade into the Investment Development Path. A case study of Korea and Taiwan. Oxford Development Studies, 29(2), 146

Dunning, J.H., Lundan, S.M. (2008). Multinational enterprises and the global economy, Cheltenham: Edward Elgar Publishing.

Ernst\&Young Report (2017). Poland's Attractiveness Survey. Mature Leader of the CEE region. Available 5.09.2018 from: www. ey.com/Publication.

Ferencikova, Sr.S., Ferencikova, Jr.S. (2012). Outward investment flows and the development Path. The case of Slovakia. Eastern European Economics, 50(2), 85-111.

Gorynia, M., Nowak, J., Wolniak, R.(2009). Poland's Investment Development Path: in search of a synthesis, International Journal of Economic Policy in Emerging Economies, 2(2), 153-174.

IMF. Available 20.08.2018 from: www.imf. org.

Krugman, P.R., Obstfeld, M. (2007). Międzynarodowe stosunki gospodarcze (International Economics: Theory and Policy). PWN, Warszawa.

NBP. Available 5.09.2018 from: http://www.nbp.pl/home.aspx?f=/publikacje/zib.

Nowara, W. (2001). Wpływ zagranicznych inwestycji bezpośrednich na gospodarkę Polski (Impact of Foreign Direct Investment on the Polish Economy). In: J. Biski, T. Miziołek (red.), Liberalizacja stosunków ekonomicznych Polski z gospodarką światową (Liberalization of Poland's Economic Relationships with the Global Economy). Łódzkie Towarzystwo Naukowe, Łódź, 318-319. 


\section{K. Żak}

OECD (2008). OECD Benchmark Definition of Foreign Direct Investment. Fourth Edition. Available 15.08.2018 from: www.oecd.org/daf/inv/investmentstatisticsandanalysis/40193734.pdf.

Rosińska-Bukowska, M.(2009). Rola korporacji transnarodowych w procesach globalizacji. Kreowanie globalnej przestrzeni biznesowej (The Role of Transnational Corporations in Globalization Processes. Creating Global Business Space). Dom Wydawniczy Duet, Białystok.

Rymarczyk, J. (2004). Internacjonalizacja i globalizacja przedsiębiorstwa (Internationalization and Globalization of the Enterprises). Polskie Wydawnictwo Ekonomiczne Warszawa.

Stawicka, M. (2008). Rola bezpośrednich inwestycji zagranicznych w zmniejszaniu dysproporcji rozwojowych nowych krajów członkowskich Unii Europejskiej (The Role of Foreign Direct Investments in Reduction of Disproportion in Development of New EU Member Countries). Nierówności Spoteczne a Wzrost Gospodarczy, 13, 295-305.

UNCTAD. Database. Available 20.08.2018 from: www.unctad.org/fdistatistics.

Żak, K. (2017). Analiza i ocena ekspansji zagranicznej polskich przedsiębiorstw (Analysis and Evaluation of Foreign Expansion of Polish Enterprises). OPTIMUM. Studia Ekonomiczne, 2(86), 74-92.

For citation:

Żak K. (2018). Poland's Position on the Investment Development Path. Problems of World Agriculture, 18(4), 515-524; DOI: 10.22630/PRS.2018.18.4.139 